[JAS 1.2 (2003) 7-9]

ISSN 1740-3553

\title{
Editorial: Fellowship, Authority and Institutions
}

\author{
Bruce Kaye
}

The publication of the first issue of the Journal of Anglican Studies has now passed into the public record and this Journal is now openly available as an arena for a scholarly conversation about the nature of the Anglican Christian tradition. The Editorial team and the Trustees are very grateful to the many people who have sent messages of encouragement and for the ready welcome the Journal has received. Now we settle to the regular business of making the Journal work and in that process we look to Anglican scholars around the globe to participate in this project.

This issue of the Journal of Anglican Studies is concerned with issues of authority and fellowship. Stephen Sykes takes up the question of the basis of fellowship in Anglicanism with an example drawn from the nineteenth century, while Philip Turner's argument is more directly shaped by the discussion in the late twentieth century. Stephen Sykes also draws attention to the work of the current Inter-Anglican Theological and Doctrinal Commission which has communion as a key issue on its agenda. In particular he draws attention to the consultative method adopted by the Commission in circulating in the Communion first a series of questions and then a set of six propositions. The Commission has invited responses to these propositions and no doubt we may reasonably expect that the Commission will find some further ways of consulting with the global Anglican community before they complete their task. This method is particularly welcome as it has the effect not only of keeping the work of the Commission in more direct contact with the thinking going on around the world, but it contributes to the conversation about the commission's very important agenda.

Mary Tanner draws on her unrivalled experience in ecumenical work to distil out some of the elements of the underlying issue of authority for Anglicans in the ARCIC debates. The ARCIC conversations are significant for Anglicans not just from the point of view of current ecumenical relations with the Roman Catholic Church, but they also provide a 
window into the way in which the two traditions work. In this respect it is very important for each of the parties to have a clear sense of their own tradition in its historical lineaments lest the debate lose the opportunity for real engagement and clarification. One of the very important matters to be clarified in this dialogue is the character of the inner dynamics and mode of operating of both parties. How the debate proceeds, therefore, is of great theological significance and this article contributes to the process of clarification on the crucial theme of authority.

Philip Freier provides a case study of the operation of aspects of authority from the history of mission. He gives us the benefit of extensive onthe-ground research on the history of the Mitchell River Mission, having worked at the mission first as a school teacher and then later as a priest.

The theme of fellowship and authority is continued in the Conversation piece of this issue. Luke Pato and Janet Trisk uncover the theological challenges of recovery in South Africa post-Apartheid. That uncovering reveals some fundamental theological issues for Anglicans which touch on problems of reconstruction and renewal in other parts of the world.

In this issue we introduce an occasional series of articles on Anglicanism and major institutions of the state. Peter Young's article begins the series with a study focused on Anglicanism and the legal tradition in Australia. Legal traditions themselves vary around the globe and throughout the history of societies in which Anglicans have lived. How Anglicans have related to institutions such as the law or the state, provide yet another window into the character of the tradition of Anglicanism. We may see this at work at close quarters in the pattern of institutionality adopted by Anglicans in the new United States of America immediately following the war of independence. The English pattern of institutionality for decision making in the church combined a set of relationships between the distinct institutions of crown, parliament and ecclesiastical structures. The Americans sought to integrate decision making within their church organizational arrangements with a set of principles which reflected their sense of the inner principles of their Anglican tradition, a matter which was the occasion of reasonably intense debate. The result also reflected some of the impulses of the contemporary cultural and intellectual assumptions coming to birth in the generation of the 'Founding Brothers', to use the felicitous phrase of J.J. Ellis. ${ }^{1}$ A similar process can be seen at work at other times in the tradition. For example, in the period immediately following the Norman Conquest the pattern of entirely integrated institutions of the Christian nation of the English was

1. J.J. Ellis, Founding Brothers: The Revolutionary Generation (New York: Vintage Books, 2002). 
changed by consolidating the national and at the same time disaggregating aspects of the institutionalities of the church and the crown.

Over a period of at least 1300 years such institutional adjustment has been one of the ways in which the tradition has sustained its inner life and managed its relationship with its host societies. A recent pointer to some institutional change in contemporary global Anglicanism is the announcement of an Anglican Gathering in 2008 to be held in connection with the Lambeth Conference in Africa. Lying behind this, as indicated by the pastoral letter from the 2003 meeting of the Primates, is the relocation of the worldwide bishops' meeting to outside of England, and most appropriately to Africa. This single decision to bring together a representative gathering of Anglicans from around the world and also the traditional Lambeth Conference of bishops and to locate both in Africa has the potential to reshape Anglican perceptions of the communion, its mission and indeed its very character.

The interplay in history between the various aspects of the tradition of Anglican life is an important part of the conversation for which the Journal of Anglican Studies exists to serve and scholars around the world are invited to contribute to that conversation in future issues of the Journal of Anglican Studies. 